ISSN 1392-3196 / e-ISSN 2335-8947

Zemdirbyste-Agriculture, vol. 106, No. 2 (2019), p. 167-172

DOI 10.13080/z-a.2019.106.022

\title{
Role of phytohormones in the formation of dwarf and tall Siberian crabapple (Malus baccata L. Borkh.)
}

\author{
Alexandr V. RUDIKOVSKII, Alexandra V. STOLBICOVA, Elena G. RUDIKOVSKAYA, \\ Luybov V. DUDAREVA
}

Siberian Institute of Plant Physiology and Biochemistry of the Siberian Branch

of the Russian Academy of Sciences

Lermontova 132, Irkutsk 664033, Russia

E-mail: ruda169@mail.ru

\begin{abstract}
Peculiarities of hormonal status of dwarf and winter hardy trees of Siberian crabapple (Malus baccata L. Borkh.) were studied. The research was carried out on plants growing in the natural habitat (western Transbaikalia, 20092010) and in a cultivated orchard (Irkutsk city, 2012-2013). The study showed that dwarfism is caused by a decline in indole-acetic acid (IAA) content and by the associated changes in the IAA:ABA (abscisic acid) content ratio in the crabapple plants in both growing conditions. During the experimental period, this ratio was above and below unity for tall and dwarf trees, respectively. The content of phytohormones remained unchanged in the studied forms in the cultivated orchard despite the increase in the growth rate of scions. It was concluded that the IAA content depended on the synthesis of the acid in the above-ground part of plants. In this context, the contribution of phytohormones to the formation of the dwarfism of $M$. baccata was discussed. We believe that the combination of winter hardiness and dwarfism in these trees make them very promising as parental forms for breeding resistant rootstocks.
\end{abstract}

Key words: abscisic acid, dwarf forms, indole-acetic acid, Malus baccata, phytohormones, Siberian crabapple.

\section{Introduction}

It is known that the growth and differentiation of a plant is determined, to a great extent, by the interaction of phytohormones of different types. A large body of research has been devoted to the study of the influence of the endogenous level of auxins, gibberellins, cytokinins, abscisic acid (ABA), ethylene, brassinosteroids and strigolactones on the morphogenesis as well as their involvement in the response of plants to external effects.

The mutual influence and cross effects of phytohormones are most clearly pronounced in their effect on growth processes. A special challenge is the effect of phytohormones on formation of the dwarfism of fruit trees (Zhang et al., 2015). Researchers have linked this phenomenon, among other things, with the ratio of indole-acetic acid (IAA) to abscisic acid (Tworkoski, Fazio, 2016). The interest in this topic is due to the obvious economic advantages of using dwarf forms as stocks for fruit trees.

ABA is a hormone that performs a variety of functions in the ontogenesis of a plant: regulation of the water exchange through the influence on stomatal conductance, participation in the response of plants to stress, inhibition of seed germination, etc. It was shown in a number of publications that dwarfism in apple plants is attributable to an increased ABA level (Lordan et al., 2017). It is most remarkable that by introducing ABA into the stem of an apple tree, it is possible to decrease the size of scions, in which case dwarf seedling stock is more sensitive to its effect than tall plants. Kamboj et al. (1999) suggest that a high ABA concentration in dwarf apple trees can influence the transport of other hormones, including IAA.

On the other hand, there is an increasing amount of data providing evidence that phytohormones can jointly regulate not only the transport but also the synthesis and stages of hormone crosstalk (Popko et al., 2010). Using Arabidopsis mutants it was shown that ABA signals are integrated into an auxin signalling pathway that involves a subset of GH3 genes encoding an auxin-conjugating enzyme. This influence is mediated by the effect of ABA on the transcription factor of R2R3 of the MYB type, which, in turn, activates the GH3 genes that are responsible for the conjugation of auxin (Seo etal., 2009).

Numerous studies have shown that endogenous content of IAA in tall plants is higher than in dwarfs ( $\mathrm{Li}$ et al., 2012; Lordan et al., 2017; Weijers et al., 2018). Besides, the auxin level is vastly higher in apexes and in other meristematic plant tissues (Ursache et al., 2013). The auxin distribution in meristematic tissues, rather than the mean auxin concentration in tree tissues, is known to be responsible for tree growth.

Please use the following format when citing the article:

Rudikovskii A. V., Stolbicova A. V., Rudikovskaya E. G., Dudareva L. V. 2019. Role of phytohormones in the formation of dwarf and tall Siberian crabapple (Malus baccata L. Borkh.). Zemdirbyste-Agriculture, 106 (2): 167-172. DOI 10.13080/z-a.2019.106.022 
In spite of a relatively large number of publications on the determination of the level of exogenous auxins in apple tree tissues, there is no agreement among the authors regarding IAA content in plants with different growth parameters. Grochowska et al. (1984) showed that the auxin level in leaves and buds of tall apple trees was higher than in dwarf ones. On the other hand, in the experiment with these plants, the gas chromatography-mass spectrometry (GC-MS) assay showed that the IAA level was higher in the buds and lower in the leaves of dwarf plants than in tall plants (Buta et al., 1989). No difference was revealed between auxin contents in the apical part of scions of normal and column-shaped apple species during the period of intense growth of new scions (Watanabe et al., 2004). In contrast to this, in an earlier publication devoted to the McIntosh cultivar 'Vijcek', it was determined that the IAA level in buds of a spur mutant was higher than in the initial cultivar of McIntosh (Looney, Lane, 1984). The studies carried out by Kamboj et al. (1999) showed that the IAA level was not significantly different in the bark of the size-controlling rootstocks. Conversely, it was shown that the IAA content was extremely high in the interstock M9 as compared to that in the scions and in the rootstock (Li et al., 2012). IAA was equally abundant in most tree components of 'Gala' on M.9 (dwarf) and MM.111 (tall) (Tworkoski, Fazio, 2016). However, in the rootstock stem below the graft and in the xylem exudate, IAA was abundant in MM.111 rootstock and absent in M.9. Tworkoski and Miller (2007) also found that the difference in the IAA content in 'Antonovka' (standard seedlings) and in dwarfing stocks was not statistically significant, but the auxin:cytokinin ratio increased in the latter ones. In their later work, Lordan and his colleagues (2017) showed a higher ABA content in the xylem exudates of the dwarfing stocks (G.11 and B.9) as compared to that in the taller forms (B.72020 and G.814). At the same time, it was found that the activity of ABA gene response and biosynthesis was decreased in the dwarfing stocks (Foster et al., 2017).

Depending on the plant organ, ABA and IAA can either have synergistic effects or counteract each other. They affect plant growth and are key elements in the formation of dwarfism. Their content and ratio in different tree organs, and also their interaction with each other and with other hormonal agents appear to be able to very subtly regulate the growth and development of the plant body on the basis of a genetically programmed scenario, and depending on the environmental conditions.

Most of the investigations into the content of phytohormones as participants in the formation of dwarfism were conducted earlier on rootstocks and cultivars belonging to the species of domestic apple (Malus domestica Borkh.) was studied. In the present work, the Siberian crabapple (Malus baccata Borkh.) was studied. Its dwarf forms occur under natural conditions near Lake Baikal (Rudikovskii et al., 2008). It should be noted that this species of apple is widely used as a valuable genetic material in domestic apple breeding for winter hardiness (Rudikovskii et al., 2008; Andreasen et al., 2014).

The study was aimed to identify a possible role of endogenous IAA and ABA content level in the formation of dwarfism in apple trees (M. baccata L. Borkh.) growing in a natural habitat and in a cultivated orchard.

\section{Materials and methods}

Plant material. Our study used the apical parts of scions $(1 \mathrm{~cm}$ shoot tip with expanding leaves removed) of skeletal twigs growing close to the vertical position. Plant material was collected in June 2009 and 2010 (for wild apple) and in June 2012 and 2013 (for introduced apple), during the period of the intensive scion growth, between 10 and 11 a.m. Plant material was then subjected to freezing in liquid nitrogen and then stored at $-70^{\circ} \mathrm{C}$. Experimental material was sampled from different forms of Siberian crabapple (Malus baccata L. Borkh.) growing in a natural habitat and in a cultivated orchard as well as trees of a dwarf form of $M$. baccata engrafted upon tall apple tree. The naturally growing trees, both dwarf and tall, which were examined in this study, occur in the region of Lake Baikal, the village of Yagodnoye $\left(51^{\circ} 24^{\prime} 05^{\prime \prime} \mathrm{N} \mathrm{103}{ }^{\circ} 30^{\prime} 30^{\prime \prime} \mathrm{E}\right), 12.5$ $\mathrm{km}$ from the city Gusinoozersk, Selenginsky district, Buryatia, Russia. The introduced apple trees grow on the experimental plot operated by Siberian Institute of Plant Physiology and Biochemistry of the Siberian Branch of the Russian Academy of Sciences, located within the precinct of the city of Irkutsk, Russia, where root shoots, taken from tall and dwarf populations were planted. The buds form of the Siberian dwarf apple trees were grafted onto tall biennial seedlings. The experiment involved 3-5 replications (with seven trees in each). All the trees were grown without irrigation. Within the first two years, the planted root shoots were cut off for the formation of a single-stem tree with a vertical trunk. Field moisture content in the soil and total field moisture capacity (FMC) were determined by the commonly accepted technique (Вадюнина, Корчагина, 1986). The soil moisture content percentage of the FMC was slightly decreased $(60 \%)$ as compared to the optimal one in the habitat of dwarf forms of $M$. baccata. The monthly mean air temperature in the area of the city of Gusinoozersk in June 2009 was $19.8^{\circ} \mathrm{C}$, and the air humidity amounted to $47.5 \%$ (http://rp5.ru/). In June 2012 and 2013, on the territory of the Siberian Institute of Plant Physiology and Biochemistry of the Siberian Branch of the Russian Academy of Science's experimental plot, the soil moisture content percentage of the FMC made up about $80 \%$, the air humidity constituted $66.3 \%$, and the monthly mean air temperature was $17.6^{\circ} \mathrm{C}$ (http://rp5.ru/).

Extraction of phytohormones. Previously weighed from 0.5 to $1 \mathrm{~g}$, apical parts of scions were homogenized in liquid nitrogen. A 4-methoxybenzoic acid as the internal standard (Fluka, USA) was used. The extraction of phytohormones was carried out with $80 \%$ methanol (sodium diethyl carbonate was used as antioxidant) in an ultrasonic bath for $10 \mathrm{~min}$ at $4{ }^{\circ} \mathrm{C}$. Centrifugation lasted $20 \mathrm{~min}$ at $20000 \mathrm{~g} \mathrm{t}=4^{\circ} \mathrm{C}$ with a centrifuge Allgra $^{\mathrm{TM}}$ 64R (Beckman Coulter, USA). The supernatant was oxidized with formic acid of up to $0.5 \%$ solution. Then the sample was cleaned from pigments with Sep-Pak $\mathrm{C}_{18}$ (Waters \& Associates, Ireland). Methanol was removed with the rotary evaporator at $30^{\circ} \mathrm{C}$, then increased to $5 \mathrm{~mL}$ with deionized water and oxidized with formic acid $(0.5 \%)$ to $1 \%$ solution and applied onto holder Oasis Max (Waters \& Associates). The holder was rinsed successively with $5 \% \mathrm{NH}_{4} \mathrm{OH}$ and $100 \%$ methanol. The sample was eluted with $2 \%$ formic acid in methanol and removed using the rotary evaporator until the sample was completely dry. The analysis by the GC-MS method employed trimethylsilyl derivatives using $\mathrm{N}, \mathrm{O}$ bis (trimethylsilyl) trifluoroacetamide (BSTFA) (Sigma, USA), for $30 \mathrm{~min}$ at $70^{\circ} \mathrm{C}$. Indole-acetic acid (IAA) and abscisic acid (ABA) were used as standards (Sigma).

Chromatography-mass spectrometry. The cleaned extracts were analysed using the gasliquid chromatography with a chromatographymass spectrometer 5973N/6890N MSD/DS (Agilent Technology, USA). The volume of the introduced sample was $2 \mu \mathrm{L}$. 
The temperatures of the evaporator, the source of ions, the detector and AUX line were 250, 230, 150 and $280^{\circ} \mathrm{C}$, respectively. The scanning range was $41-450$ atomic mass units. Capillary column: HP-5MS (30 m $\times$ $0.250 \mathrm{~mm} \times 0.50 \mu \mathrm{m})$, the fixed phase was $5 \%$-phenylmethyl-polysiloxane, the temperature gradient varied from $70^{\circ} \mathrm{C}$ to $280^{\circ} \mathrm{C}$ at a rate of $5^{\circ} \mathrm{C} \mathrm{min}{ }^{-1}$, and then from $280^{\circ} \mathrm{C}$ to $300^{\circ} \mathrm{C}$ at a rate of $20^{\circ} \mathrm{C} \mathrm{min}^{-1}$. The mobile phase was helium, and the gas flow velocity was $1 \mathrm{~mL} \mathrm{~min}^{-1}$. The flow separation was $5: 1$. The quadrupole mass spectrometer and electron ionization (or electron impact) mode were used (with the ionization energy of $70 \mathrm{eV}$ ). The analysis was carried out in the mode of selected ion monitoring. The characteristic ions of the trimethylsilyl (TMS) derivatives were: 4-methoxybenzoic acid (internal standard) - 267, 223, 193, 282 and 73, IAA - 202, 319, 203 and 304, and ABA - 190, 183, 134 and 162. Identification of phytohormones was done by comparing their retention times with the retention times of the standards as well as by using the software NIST 08 Mass Spectral Library, version 2.0 (GC Image, USA).

Statistical analysis. Each experiment was performed in five biological replicates from each tree. A statistical processing of results was carried out using the software package Microsoft Excel (2007) and Statistica 12 (StatSoft Inc., USA). Standard deviations were provided for all the results obtained. The normality of the distribution was assessed using the Shapiro-Wilk criterion. The significance of differences between the treatments was determined using Student's $t$-criterion $(P \leq 0.05)$.

\section{Results}

The natural habitats of wild tall and dwarf forms of $M$. baccata are characterised by a dry, continental climate. It is rare for the annual precipitation to exceed $200 \mathrm{~mm}$, with wintertime precipitation contribution to supplying moisture to intermountain depressions being exceptionally little, because the frequently occurring winds (in winter and, especially, in spring) blow away nearly $80 \%$ of the shallow snow cover. The plants were evolving under conditions of low moisture content in the air. It should be noted that naturally occurring tall $M$. baccata trees grew on soils with a moisture content approaching an optimal one, i.e. $77 \%$ of an ultimate field moisture capacity (FMC), due to the immediate vicinity to a mountain creek nearby. The group of dwarf plants growing in natural habitat consisted of trees whose height did not exceed $120 \mathrm{~cm}$ : the parameter of the tallest plant that was discovered in the population. Furthermore, the age of the tallest plant was 22 years, with the stem $2.2 \mathrm{~cm}$ in diameter. Plants of this kind were characterized by a very small number of branches, which were developing not in the apical part of the crown but in its middle part and were growing in a nearly horizontal position producing a crowded crown. No changes were identified in the diameter of the trunk for the plants that grew during the 2009 season. It was found that the length of annual increment in the tall trees, growing in natural habitat, was $12.1 \pm 0.78 \mathrm{~cm}$. The insignificant increase in the trunk diameter averaged $1 \mathrm{~mm}$.

Our experiments showed that the content of endogenous IAA in the shoot tips of the natural dwarf and tall forms of $M$. baccata differed drastically. Thus, the auxin content in dwarf trees was as high as $116 \mathrm{ng}$ $\mathrm{g}^{-1}$ of dry weight (DW), whereas its content in the tall form was three times as high, $350 \mathrm{ng} \mathrm{g}^{-1}$ of DW (Fig. 1). ABA content in the shoot tips was almost the same in the two forms under study (210 and $213 \mathrm{ng} \mathrm{g}^{-1}$ of DW in the

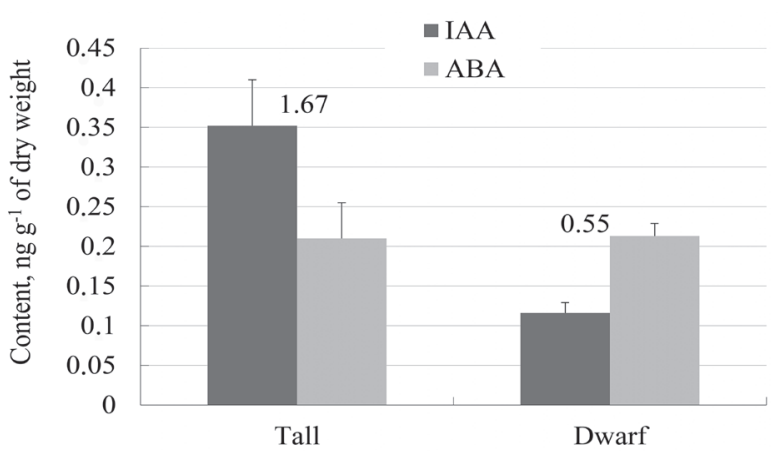

Note. $1.67,0.55$ is the ratio of IAA:ABA for different forms.

Figure 1. The content of indole-acetic acid (IAA) and abscisic acid (ABA) in the shoot apex of the Malus baccata, grown under natural conditions

tall and dwarf forms of the plants, respectively). In all cases, the IAA:ABA ratio for tall plants was above unity, or 1.67 , and for dwarf plants it was below unity, or 0.55 .

In this respect, it was of interest to study the changes in the content of phytohormones when the plants were introduced in the more favourable (as regards the water availability) conditions of the city of Irkutsk.

It was found that when $M$. baccata plants were grown under more favourable conditions, the contents of these two hormones were roughly the same. Thus, the content of IAA in the shot tips of tall apple was $325 \mathrm{ng} \mathrm{g}^{-1}$ of DW, whereas that in dwarf apple was three times lower, i.e. $101 \mathrm{ng} \mathrm{g}^{-1}$ of DW. The ABA contents in the two forms under investigation did not differ as compared to similar natural forms: $186 \mathrm{ng} \mathrm{g}^{-1}$ of DW for tall plants and $212 \mathrm{ng} \mathrm{g}^{-1}$ of DW for dwarf plants, but they did not differ from each other as significantly as did the former. Besides, the IAA:ABA ratio was always higher in tall plants no matter under what conditions they grew: 1.75 for tall plants and 0.48 for dwarf plants (Fig. 2).

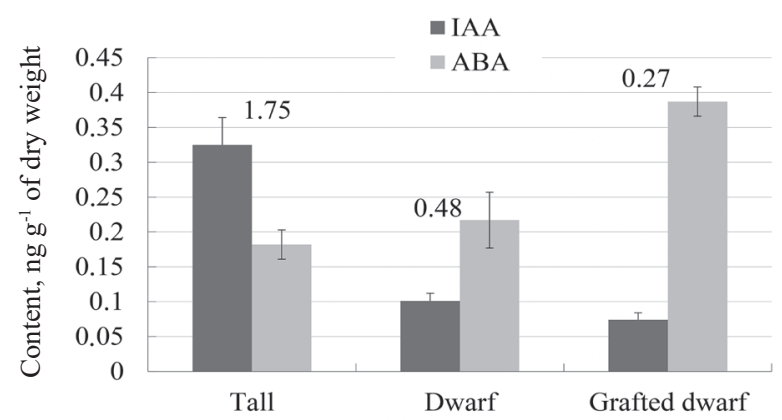

Note. $1.75,0.48,0.27$ is the ratio of IAA:ABA for different forms.

Figure 2. The content of indole-acetic acid (IAA) and abscisic acid (ABA) in the shoot apex of the Malus baccata grown in a cultivated orchard

It was observed that under more favourable water availability conditions in the cultivated orchard, the growth of the studied forms increased in comparison with those in the natural habitat. Furthermore, the seasonal increment of scions in tall apple was about twice as high as in dwarf apple (Fig. 3).

Toward the end of the season, tall apple was substantially ahead of dwarf apple by the main attributes (tree height and trunk diameter) characterizing the growth parameter of the tree (Table 1).

The measurements of the introduced forms that are provided in Table 1 confirmed the substantial 


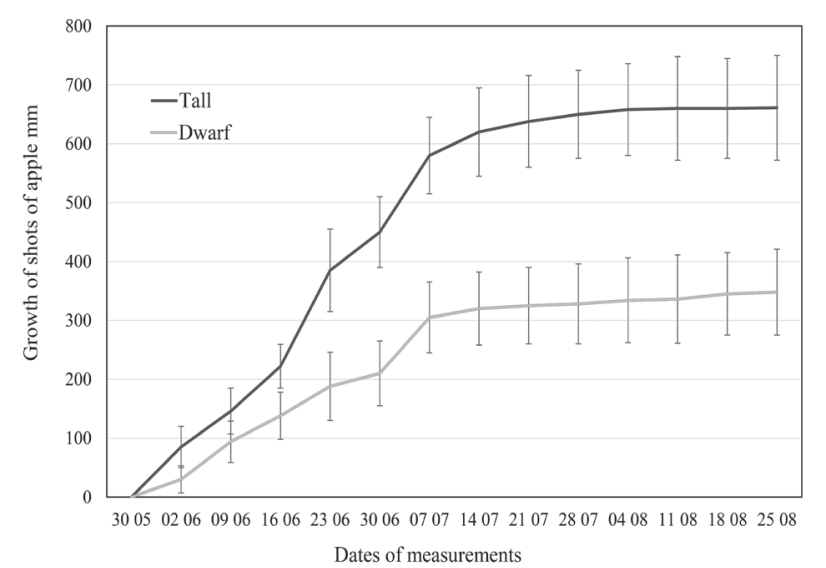

Figure 3. Growth of shoots of dwarf and tall forms of introduced Malus baccata during the growing season influence of the decreased level of free auxin in the apical part of the scions on the formation of a peculiar bushy form of the dwarf tree associated with a disturbance of the apical dominance.

In order to more comprehensively study the influence of IAA and ABA on the growth of M. baccata trees, the dwarf and tall forms were grafted onto a 2-yearold tall rootstock. This experiment clearly showed a difference in the development of tall and dwarf scions on this rootstock. An analysis of the annual growth in the trunk diameter and the number of internodes revealed that suckers in dwarf grafts (skeletal twigs) developed more intensively (Table 2). This, along with the inhibited growth of the central scion, gave rise to a bushy dwarf form similar to the one of the trees growing on their own roots, both under natural habitat and in a cultivated orchard.

It was also noticed that in the tissues of the dwarf apple grafted on a tall rootstock there was a dramatic increase in ABA content (387 $\mathrm{ng} \mathrm{g}^{-1} \mathrm{DW}$ ) as compared

Table 1. Growth parameters of three-year-old dwarf and tall forms of Malus baccata trees grown in a cultivated orchard

\begin{tabular}{lcc}
\hline \multicolumn{1}{c}{ Parameter } & Dwarf & Tall \\
\hline Tree height $\mathrm{m}$ & $1.34 \pm 0.25^{*}$ & $2.39 \pm 0.44$ \\
Trunk diameter cm & $1.92 \pm 0.20^{*}$ & $2.15 \pm 0.40$ \\
Number of internodes on annual growth of the third year & $35.6 \pm 4.5^{*}$ & $25 \pm 3$ \\
Length of annual growth of the third year cm & $1.2 \pm 0.2 *$ & $67.3 \pm 5.1$ \\
Skeletal branches with length less than $5 \mathrm{~cm}$ & $7.3 \pm 0.5 *$ & $8.9 \pm 0.6$ \\
Skeletal branches with length more than $5 \mathrm{~cm}$ & $2.2 \pm 0.7$ & $1.5 \pm 0.2$ \\
Internode length cm & $0.34 \pm 0.10$ & $2.5 \pm 0.8$ \\
Thickness of annual growth of the third year mm & & $0.44 \pm 0.12$ \\
\hline
\end{tabular}

* - significant at $P<0.05$

Table 2. Growth parameters of one-year grafting of dwarf and tall forms of Malus baccata trees on tall rootstock

\begin{tabular}{lcc}
\hline \multicolumn{1}{c}{ Parameter } & Dwarf & Tall \\
\hline Annual growth of grafting cm & $66.8 \pm 10.9^{*}$ & $112 \pm 13$ \\
Trunk diameter cm & $0.9 \pm 0.1^{*}$ & $1.43 \pm 0.2$ \\
Number of internodes on annual growth of grafting & $26 \pm 4^{*}$ & $49 \pm 5$ \\
Average length of skeletal branches cm & $21.47 \pm 2.13^{*}$ & $9.67 \pm 2.67$ \\
Internode length cm & $2.20 \pm 0.54$ & $2.23 \pm 0.49$ \\
Thickness of annual growth of grafting cm & $0.3 \pm 0.1$ & $0.39 \pm 0.12$ \\
\hline
\end{tabular}

* - significant at $P<0.05$

to that in the own-rooted apple tree plants. Conceivably, this was associated with a poor compatibility between the rootstock and the graft. In this case, as with the other dwarf plants, the IAA:ABA ratio was less than unity, or 0.27 .

\section{Discussion}

The analysis of the results obtained allows us to conclude that the formation of a dwarf habitus in $M$. baccata appears to be associated with the decreased content of free IAA in the shoot tips. Such a tendency was observed under natural conditions as well as in a cultivated orchard and grafting onto a tall rootstock. This implied a more intense growth of skeletal twigs as compared to the tall forms. A similar form of the crown was produced by dwarf apples in the natural habitat as well (Rudikovskii et al., 2008). An investigation into content of phytohormones in dwarf grafts showed that the IAA level in the shoot tips of such plants was insignificantly lower $\left(74 \mathrm{ng} \mathrm{g}^{-1} \mathrm{DW}\right)$ than that in the introduced dwarf apple growing on its own roots (Fig. 2). This suggests that the auxin level and the growth rate of the above-ground part of the tree depend not on the activity of the root system and hormonal signals from it, but on the synthesis of IAA in the apical part of the scions, in young leaves and on the basipetal transport of this hormone. On the other hand, it was established (Noda et al., 2000) that tall rootstocks that were grafted onto dwarf rootstocks were characterized by a decrease in the level of endogenous IAA. This observation is supported by a well-established fact that the intercalary insertion from dwarf forms acts in itself as a dwarf rootstock (Webster, 2010). Thus, the peculiarities of apple trees in the rootstock / graft system are still a complex and understudied problem.

The polar transport of IAA in trees is known as a critical component sustaining the structure and activity of vascular cambium the activity of which maintains the secondary growth within the trunk (Source et al., 2013). The importance of the basipetal polar transport of IAA was demonstrated by girdling the trunk and removing apical buds. Ring-girdling led to build-up of tracheids and to an increase of the IAA level above the ring, while decapitation led to a decrease in products of tracheids and in IAA concentration. As shown in Soumelidou et al. (1994), the rate of basipetal transport of labelled indoleacetic acid was higher in tall rootstock M.111 than in dwarf rootstock M.9. The authors suggest that the slower transport of a smaller amount of IAA eventually leads to formation of a decreased number of xylem vessels, which is so characteristic of dwarf forms of apple. According to the aforementioned logic pattern, the decrease in the growth rate of dwarf forms of $M$. baccata appears quite explicable from this standpoint.

Gibberellin (GA) is known to stimulate stem and leaf growth. The combined action of GAs and IAA has a synergistic effect on the growth of the plant. 
As the exogenous inhibitor treatment of the auxin transport significantly reduces the GA level in the scions, it is believed that a dwarfing stock can decrease the IAA transport, and thus lower amount of IAA can be found in the root system. This leads to the limited synthesis of GAs in the roots and to the decrease in their transfer to the above-ground part of the plant. That is the way the dwarf trees are formed (Liu et al., 2017). After applying exogenous GA3 to the apical parts of the shoots of dwarf form $M$. baccata, was observed a significant increase in the processes of growth of these shoots compared to those of the shoots without application of GA3 (Stolbikova et al., 2018). The sensitivity to this hormone which is manifested in the M. baccata dwarf trees can be connected with the perturbations in GA biosynthesis or with the accumulation of the repressors of GA signalling - DELLA proteins.

The influence of endogenous ABA on the growth is a more complex issue. A considerable amount of literature points to its role as a growth inhibitor under conditions of stress. On the other hand, however, ABA was also described as an element sustaining the growth in different tissues of some plant species when they are under conditions of salinity, cold, heat, drought and soil firmness. At that, ABA-deficient mutants of some plant species are not infrequently smaller in size and have smaller leaves as compared to wild types; however, their growth is enhanced considerably in the presence of exogenous ABA (Popko et al., 2010). It was suggested that $\mathrm{ABA}$ is the growth inhibitor under conditions of stress, yet it maintains the growth under control (not stress) conditions (Barrero et al., 2005).

Dwarfism in apple is often associated with an increase in ABA content (Tworkoski, Fazio, 2016; Lordan et al., 2017). It was shown that bark of dwarf apple and citrus contains more ABA as compared to that of tall forms (Kamboj et al., 1999; Noda et al., 2000). Exogenous ABA, when applied onto leaves of two species of apple (Malus sieversii and M. hupehensis) caused a decrease in the growth, the biomass, the total area of leaves, and a shortening of internodes (Ma et al., 2008).

Our experiment revealed no differences in the ABA content in the shoot tips of $M$. baccata forms differing in size which grew under identical conditions. A large amount of ABA was observed in the treatment with dwarf apple grafted onto a tall rootstock. Perhaps this is due to incomplete compatibility between the stock and the graft.

It is known that the functional mutual influence of phytohormones is of considerable importance for the growth and development of plants; this is particularly true in regard to abiotic stress. Furthermore, the interaction of hormones can be nonlinear and can result from their interinfluence. Evidence for such an interaction is obtained by studying mutants with a decreased receptivity to ABA or auxins as well as plants with superexpression of crosstalk components of these hormones (Popko et al., 2010). Furthermore, some of the mutants exhibit a pleiotropic effect suggesting that mutant genes or increased expression of proteins influence crosstalk transduction of IAA and ABA. Methods of this kind were used to demonstrate, for example, that the intersection place of crosstalk of ABA and auxins is provided by transcription factor $\mathrm{ABI} 3$ that is involved in the transduction of the ABA signal. In this regard, the use of IAA:ABA ratio as an indicator characterizing the growth rate appears to be logical.

The IAA:ABA ratio in dwarf and tall M. baccata differs noticeably. In tall apples (natural and introduced), this ratio was greater than unity, whereas in dwarf apples, in both growing conditions, it was less than unity. According to published data, the content of free ABA in the apical parts of scions of domestic apple, on the contrary, exceeded the content of free IAA (Tworkoski, Miller, 2007). This same regularity is observed in citrus plants (Noda et al., 2000; 2001). Besides, there is no intimate connection between the IAA:ABA ratio and the degree of dwarfism in domestic apple. For example, 'Jonathan' apple trees are considered medium according to IAA:ABA ratio of 0.2 (Noiton et al., 1992). The semi dwarf rootstock M.7 of apple showed a smaller IAA:ABA ratio (0.34), whereas dwarf rootstock M.9 showed a larger ratio $(0.49)$. The same situation is also characteristic of citrus plants (Noda et al., 2001). On the contrary, for M. baccata, a high growth rate of trees, based on the increased ratio (IAA:ABA > 1), can be suggested.

\section{Conclusion}

The research reported in this paper showed that in Siberian crabapple (Malus baccata L. Borkh.) the formation of dwarf forms is associated not with the expected changes in the abscisic acid (ABA) level, but with a decrease of indole-acetic acid (IAA) content in the shoot tips (growing point / vegetative apex and young unfolding leaves). Furthermore, the IAA content level depends on the intensity of its synthesis in the aboveground part of the plant. As the numerical value of ABA:IAA ratio for the dwarf apple is less than unity in all the cases, the ratio may well serve as a diagnostic one when determining the habitus of $M$. baccata at early growth stages. The fact that hormone ratio and content in both $M$. baccata forms remained unchanged in a cultivated orchard regardless of the increase in the scions growth rate allows us to suppose that these parameters are genetically predetermined.

\section{Acknowledgments}

This study is financially supported by Russian Foundation for Basic Research (RFBR) (08-022-98064). The authors thank Dr. A. Yazeva for help in translating the article.

Received 11042018

Accepted 16102018

\section{References}

1. Andreasen K., Manktelow M., Sehic J., GarkavaGustavsson L. 2014. Genetic identity of putative Linnaean plants: Successful DNA amplification of Linnaeus's crab apple Malus baccata. Taxon, 63 (2): 408-416. https://doi.org/10.12705/632.14

2. Barrero J. M. Piqueras P, Gonzárlez-Guzmán M. Serrano R., Rodríguez P. L., Ponce M. R., Micol J. L. 2005 A mutational analysis of the $A B A 1$ gene of Arabidopsis thaliana highlights the involvement of ABA in vegetative development. Journal of Experimental Botany, 56 (418): 2071-2083. https://doi.org/10.1093/jxb/eri206

3. Buta J. G., Reed A. N., Murti G. S. 1989. Levels of indole3 -acetic acid in vigorous and genetic dwarf apple trees. Journal of Plant Growth Regulation, 8: 249-253. https://doi.org/10.1007/BF02308093

4. Foster T. M., McAtee P. A., Waite C. N., Boldingh H. L., McGhie T. K. 2017. Apple dwarfing rootstocks exhibit an imbalance in carbohydrate allocation and reduced cell growth and metabolism. Horticulture Research, 4: 17009. https://doi.org/10.1038/hortres.2017.9

5. Grochowska M. J., Buta J. G., Steffens G. L., Faust M. 1984. Endogenous auxin and gibberellin levels in low and high vigor apple seedlings. Acta Horticulturae, 146: 125-134. https://doi.org/10.17660/ActaHortic.1984.146.13

6. Kamboj J. S., Browning G., Blake P. S., Baker D. A. 1999. GC-MS-SIM of abscisic acid and indole-3-acetic acid in shoot bark of apple rootstocks. Journal of Plant Growth Regulation, 28 (1): 21-27. https://doi.org/10.1023/A:1006299414481 
7. Li H. L., Zang H., Yu C., Ma L., Wang Y., Zhang X. Z., Han Z. H. 2012. Possible roles of auxin and zeatin for initiating the dwarfing effect of M9 used as apple rootstock or interstock. Acta Physiologia Plantarum, 34 (1): 235-244. https://doi.org/10.1007/s11738-011-0822-9

8. Liu X.-Y., Li J., Liu M.-M., Yao Q., Chen J.-Z. 2017. Transcriptome profiling to understand the effect of citrus rootstocks on the growth of 'Shatangju' mandarin. PLoS ONE, 12 (1): e0169897.

https://doi.org/10.1371/journal.pone.0169897

9. Looney N. E., Lane W. D. 1984. Spur-type growth mutants of McIntosh apple: a review of their genetics, physiology and field performance. Acta Horticulturae, 146 (2): 31-45. https://doi.org/10.17660/ActaHortic.1984.146.2

10. Lordan J., Fazio G., Francescatto P., Robinson T. 2017. Effects of apple (Malus $\times$ domestica) rootstocks on scion performance and hormone concentration. Scientia Hortculturae, 225: 96-105. https://doi.org/10.1016/j.scienta.2017.06.050

11. Ma X., Ma F., Mi Y., Ma Y., Shu H. 2008. Morphological and physiological responses of two contrasting Malus species to exogenous abscisic acid application. Plant Growth Regulation, 56: 77-87. https://doi.org/10.1007/s10725-008-9287-2

12. Noda K., Okuda H., Iwagaki I. 2000. Indole acetic and abscisic acid levels in new shoots and fibrous root of citrus scion-rootstock combination. Scientia Horticulturae, 84 (3): 245-254. https://doi.org/10.1016/S0304-4238(99)00080-1

13. Noda K., Okuda H., Iwagaki I. 2001. Relationship between growth and IAA and ABA levels in citrus rootstock seedlings. Journal of the Japanese Society for Horticultural Science, 70 (2): 258-260 https://doi.org/10.2503/jishs.70.258

14. Noiton D., Vine J. H., Mullins M. G. 1992. Effects of serial subculture in vitro on the endogenous levels of indole-3 acetic acid and abscisic acid and rootability in microcuttings of 'Jonathan' apple. Plant Growth Regulation, 11 (4): 377-383. https://doi.org/10.1007/BF00130645

15. Popko J., Hänsch R., Mendel R.-R., Polle A., Teichmann T. 2010. The role of abscisic acid and auxin in the response of poplar to abiotic stress. Plant Biology, 12 (2): 242-258. https://doi.org/10.1111/j.1438-8677.2009.00305.x

16. Rudikovskii A. V., Rudikovskaya E. G., Dudareva L. V., Kuznetsova E. V. 2008. Unique and rare forms of Siberian apple tree in Selenga district of Buryatia. Contemporary Problems of Ecology, 2: 327-333.

17. Seo P. J., Xiang F., Qiao M., Park J.-Y., Lee Y. N., Kim S. G., Lee Y.-H., Park W. J., Park C. M. 2009. The MYB96 transcription factor mediates abscisic acid signaling during drought stress response in Arabidopsis. Plant Physiology, 151: 275-289. https://doi.org/10.1104/pp.109.144220
18. Soumelidou K., Morris D. A., Battey N. H., Barnett J. R., John P. 1994. Auxin transport capacity in relation to the dwarfing effect of apple rootstocks. Journal of Horticultural Science, 69 (4): 719-725. https://doi.org/10.1080/14620316.1994.11516505

19. Source C., Giovannelli A., Sebastiani L., Anfodillo T. 2013. Hormonal signals involved in the regulation of cambial activity, xylogenesis and vessel patterning in trees. Plant Cell Report, 32: 885-898. https://doi.org/10.1007/s00299-013-1431-4

20. Stolbikova A. V., Shishparenok A. A., Rudikovskiy A. V., Rudikovskaya E. G., Dudareva L. V. 2018. Possible involvement of gibberellins in the formation of dwarf varieties of Siberian crabapple Malus baccata (L.) Borkh. In the conditions of forest-steppe ecotone. Siberian Journal of Forest Science, 1: 59-64 (in Russian).

21. Tworkoski T., Miller S. 2007. Endogenous hormone concentrations and bud-break response to exogenous benzyl adenine in shoots of apple trees with two growth habits grown on three rootstocks. The Journal of Horticultural Science and Biotechnology, 82 (6): 960-966.

https://doi.org/10.1080/14620316.2007.11512333

22. Tworkoski T., Fazio G. 2016. Hormone and growth interactions of scions and size-controlling rootstocks of young apple trees. Plant Growth Regulation, 78 (1): 105-119. https://doi.org/10.1007/s10725-015-0078-2

23. Ursache R., Nieminen K., Helariutta Y. 2013. Genetic and hormonal regulation of cambial development. Physiologia Plantarum, 147: 36-45. https://doi.org/10.1111/j.1399-3054.2012.01627.x

24. Watanabe M., Suzuki A., Komori S., Bessho H. 2004. Comparison of endogenous IAA and cytokinins in shoots of columnar and normal type apple trees. Journal of the Japanese Society for Horticultural Science, 73 (1): 19-24. https://doi.org/10.2503/jjshs.73.19

25. Webster A. D. 2010. Rootstock and interstock effects on deciduous fruit tree vigour, precocity, and yield productivity. New Zealand Journal of Crop and Horticultural Science, 23: 373-382. https://doi.org/10.1080/01140671.1995.9513913

26. Weijers D., Nemhauser J., Yang Z. 2018. Auxin: small molecule, big impact. Journal of Experimental Botany, 69 (2): 133-136. https://doi.org/10.1093/jxb/erx463

27. Zhang H., An H. S., Wang Y., Zhang X. Z., Han Z. H. 2015. Low expression of PIN gene family members is involved in triggering the dwarfing effect in M9 interstem but not in M9 rootstock apple trees. Acta Physiologia Plantarum, 37: 104. https://doi.org/10.1007/s11738-015-1851-6

28. Вадюнина А. Ф., Корчагина 3. А. 1986. Методы исследования физических свойст почвы. Москва, Россия, 416 с. (in Russian)

ISSN 1392-3196 / e-ISSN 2335-8947

Zemdirbyste-Agriculture, vol. 106, No. 2 (2019), p. 167-172

DOI $10.13080 /$ z-a.2019.106.022

\title{
Fitohormonų įtaka formuojantis aukštaūgiams ir žemaūgiams Sibirinės uoginės obels (Mallus baccata L. Borkh.) augalams
}

\author{
A. V. Rudikovskii, A. V. Stolbicova, E. G. Rudikovskaya, L. V. Dudareva \\ Rusijos mokslų akademijos Sibiro augalų fiziologijos ir biochemijos institutas
}

\section{Santrauka}

Tirta žemaūgių ir šalčiui atsparių Sibirinès uoginès obels (Malus baccata L. Borkh.) medžių hormonų būklès ypatumai. 2009-2010 m. tyrimas buvo atliktas su augalais, augančiais natūraliose augavietėse Vakaru Transbaikalo regione, 2012-2013 m. - sode Irkutsko mieste, Rusijoje. Tyrimo duomenys parodè, kad žemaūgiškumą lemia sumažejęs indolilacto rūgšties (IAR) kiekis ir su tuo susiję IAR:ABR (abscizo rūgšties) santykio pokyčiai uoginėse obelyse, augusiose abiejose sąlygose. Tyrimo metu šis už vienetą didesnis santykis buvo nustatytas aukštaūgèse, mažesnis - žemaūgėse obelyse. Fitohormonu kiekis liko nepakitęs tirtose obels formose sode, nepaisant didesnio ūglių augimo greičio. Padaryta išvada, kad IAR kiekis priklauso nuo šios rūgšties sintezès augalo antžeminèje dalyje. Šiame kontekste aptarta fitohormonų įtaka M. baccata rūšies žemaūgiškumo formavimuisi. Dèl atsparumo šalčiui ir žemaūgiškumo šie medžiai yra perspektyvios tėvinės formos kuriant poskiepius.

Reikšminiai žodžiai: abscizo rūgštis, fitohormonai, indolo acto rūgštis, Malus baccata, Sibirinė uoginė obelis, žemaūgès formos. 